\title{
Sustainable Forest Management Crisis and Bribery in Cameroon: An Empirical Investigation of the Mookherjee and P'ng Model
}

\author{
Siméon Maxime Bikoué \\ Advanced School of Economics and Commerce, University of Douala, Cameroon P.O. Box 1931, Douala, \\ Cameroon
}

\begin{abstract}
The author tries to use the Mookherjee and P'ng model to analyze bribery as one of the key explanatory variables for the sustainable forest management crisis in Cameroon. The analysis of field data shows that the public administration of forest in this country does not have the incentive and dissuasive instruments recommended by the anti-bribery model. The author therefore recommends that the Administration should use these instruments in an attempt to remedy the crisis.
\end{abstract}

Keywords: Bribery - Sustainable Management - Crisis - Forest Ecosystem - Regulation - Law - Biodiversity Destruction - Degradation

DOI: $10.7176 / \mathrm{JESD} / 11-16-20$

Publication date:August $31^{\text {st }} 2020$

\section{Introduction}

Since the beginning of the 1990s, the sustainable management of Cameroon's forests has been in crisis. Three sets of analyzes have been put forward so far to explain the origin of the crisis.

First of all, the early analyzes highlighted the inability of successive governments to pursue a real sustainable forest management policy, i.e. management that meets the needs of present generations without compromising the ability of future generations to satisfy theirs [Brundland G. H. (1998), Lauriol J. (2004), Capul J.Y., Garnier (2005)]. Then, other analyzes found that the crisis stems from lack of information concerning the real potential of Cameroonian forestry. Finally, other analyzes have rather questioned the fact that the demographic pressure on forest resources has intensified. To these relevant factors and for a better understanding of the origins and extent of the crisis in the forest sector, it is essential to add bribery as an essential variable for both the severity of the destruction and degradation process of the forest, and the difficulties in enforcing the regulations. Adding bribery is more than ever relevant because since the beginning of the 1990s, the right to exploit some tree species and not others is no longer enforced in accordance with the legal requirements as it used to be. In fact, logging companies can now cut off forbidden species once they have bribed public forest controllers.

Corrupt behaviors have profoundly affected the functioning of the forest sector and continue to play a decisive role in how restructuring this sector evolves. In fact, such behaviors have distorting effects on decisions to grant forest exploitation licenses, declarations of quality and quantity of trees cut off, the right to cut some species and not others, and they continue to influence the movements of tax revenues and the process of paying fines; thus interfering with forest conservation strategies and, in turn, biodiversity.

To understand the impact of bribery, we can base our analysis on the contributions of rent-seeking theory in general, and the Mookherjee and P'ng (1995) model in particular; this will enable us to account for the nature of the relationship between bribery, forest degeneration and regulation enforcement, and to consider the consequences of the strategic interaction between ecosystem-destroying logging companies and corrupt public controllers.

The purpose of this paper is to contribute, in the light of the Mookherjee and P'ng model, to the analysis of the phenomenon of bribery and its effects on the crisis of the forestry sector in Cameroon. More precisely on the basis of field surveys, the question is whether the Forest System Regulator, namely the Ministry of Environment and Forests (MINEF), uses for sustainable management of the forest ecosystem, instruments such as the reward rate of public forest controllers, the penalty rates imposed on these public controllers as well as corrupt logging companies.

The rest of the article is structured as follows: the second section presents the teachings of the Mookherjee and P'ng model; the third is devoted to the description of bribery in public forest administrations and its impact on the sustainable management of forest resources; the fourth is the conclusion.

\section{The model}

Trees are important to any society. However, when such a natural resource is abundant, its exploitation gives rise to rent-loving behaviors (Leite C., Weidman J, 1999, Aidt, Toke S. 2003, 2009, 2012,). Thus, in a national forest management system consisting of a Regulating Ministry and controllers empowered by the Ministry to report on forest degradation and/or deforestation due to logging activities, corrupt behaviors can be particularly important in forest conservation strategies; and thus, in the preservation of biodiversity. These behaviors will depend in part 
on the relationships that controllers have with the Regulating Ministry and, on the other hand, on their links with logging companies. Mookherjee and P'ng study the interrelations between the actors that are: the regulator, the controller and the forest operator. To fully understand these interconnections, we will first set the scene before analyzing how bribery occurs.

\subsection{Staging the actors}

By cutting down a volume A of forbidden trees, a logging company can avoid the legal provisions that would cost $C(A)$. The cost thus avoided is private profit. We assume that $C(0)=0, C(A)$ is strictly increasing, strictly concave and differentiable, and $\mathrm{C}^{\prime}(\mathrm{A})=0$ at the point where $\mathrm{A}=\tilde{\mathrm{A}}$. The volume of forbidden yet actually cut trees generates a nuisance $h(A)$ where $h(A)$ is strictly increasing, convex and differentiable and $h(0)=0$. Note the level of degradation that maximizes the net profit, $C(A)$ - h (A), by $A$ *.

This first-rank optimum can be socially optimal if the application of the law was costless.

Generally, $A * \geq 0$ where $A *>0$ means that it is socially optimal to allow some level of forest degradation.

According to the law, degradation is subject to a fine $\mathrm{fA}$, (where $\mathrm{f}$ is an exogenous and finite rate), and the head of the law enforcement agency employs an inspector to implement this regulation. To control the operator with an intensity $\mu$, the controller must make an unobservable effort e $(\mu)$, where e $(\mu)$, is strictly increasing, strictly connected and differentiable, and e $(0)=0$. This intensity $\mu[0,1 \neg \neg]$ represents the probability that the controller will find out the true level of degradation caused by the logging company A, and successfully prosecute the company. With probability $1-\mu$, the controller will not get any obvious level of degradation. We assume that the logging company is aware of what the controller has found.

The controller has full command of not only the choice of the intensity of his effort, but the level of the volume of forbidden, yet actually cut trees $\hat{A}$, which he reports to the regulator. To motivate the controller, the regulator pays him a reward for every dollar of degradation discovered and produced by the logging company. We assume that the penalties on the controller for excessive reporting are quite high and that the costs of the logger victim of this report are low enough, so that the controller will never be able to make an excessive report, thus, $\hat{\mathrm{A}}$ $\leq$ A.

The logging company may corrupt the controller to report a lower level of degradation than in reality. By doing so, the operator can reduce his fine from fA to $\mathrm{f}$ while the controller receives a small reward. In such circumstances, we assume that information on bribery and the actual degradation of Operator A will reach the regulator with an exogenous probability. The source of the leak of information may be verified by another government agency, by the press or employees dissatisfied with the operator. Information leaks reveal bribes paid by the operator to the controller.

In the event that bribery is discovered, the operator must pay not only the amount of the escaped fine, $f$ (A$\hat{A})$, but an additional penalty for giving a bribe at the rate $p_{g}$, making a total of $\left(1+p_{g}\right) f(A-\hat{A})$.

In case of information leak, the controller must pay a penalty $\mathrm{p}_{t}(\mathrm{~A}-)$ for taking a bribe and undervaluing the report.

To summarize, the regulator's policy consists of three instruments: the reward rate, $r$, the penalty for taking a bribe, $\mathrm{p}_{\mathrm{t}}$, and the penalty for giving a bribe, pg. Given the policy $\left(\mathrm{r}, \mathrm{p}_{\mathrm{t}}, \mathrm{p}_{\mathrm{g}}\right.$ ), the operator and the controller simultaneously choose the degradation, A, the intensity of the control, $\mu$, respectively. Thus, both parties jointly determine the bribe, if any; all parties are supposed to be neutral as far as risk is concerned.

\subsection{How bribery occurs}

To begin with, suppose that the operator has degraded the forest to level A and the controller has discovered this degradation. We can identify the conditions for which there is a bribe and its amount $\mathrm{b}$. If the logging company does not corrupt the controller, it must pay a fine fÂ for the degradation. If it has to pay a bribe and bring the controller back to $\leq \mathrm{A}$, the logging company will pay a small fine to the government. However, with the possibility that information leaks and the logging company pays in addition $\left(1+p_{g}\right) f(A-\hat{A})$ to the Regulator. Thus, the logging company expects to make 1 gain of $\left[1-\left(1+p_{g}\right)\right] f(A-)-b$ of the bribe.

If the controller refuses bribery, he will receive a rf $\hat{A}$ reward from the regulator. However, if he accepts the bribe $\mathrm{b}$ and undervalues the degradation in his report, his reward will be smaller, i.e. rf, and with probability $\lambda$, he will suffer a penalty of $\mathrm{p}_{\mathrm{t}}(\mathrm{A}-\hat{\mathrm{A}})$. Therefore, the expected gain from undervaluation of the degradation is: $b-(\mathrm{rf}$ $\left.+\lambda \mathrm{p}_{\mathrm{t}}\right)(\mathrm{A}-\hat{\mathrm{A}})$.

Bribery is effective only if the logging company and the controller can both benefit. Thus, a necessary and sufficient condition for the occurrence of bribery is that $\left[1-\lambda\left(1+p_{g}\right)\right] f>r f+\lambda$ pt. (I).

The logging company and the driver are both likely to be corrupt, but the occurrence of bribery is endogenously dependent on the regulator's policy. When the bribe is profitable in the sense that politics meets (I), we assume that the logging company and the controller choose a report $\hat{A}$ to maximize their joined profits, $[(1-\lambda)$ $(1+\mathrm{pg})] \mathrm{f}(\mathrm{A}-\hat{\mathrm{A}})-(\mathrm{rf}+\lambda \mathrm{pt})(\mathrm{A}-\hat{\mathrm{A}})=[\mathrm{f}-\lambda \mathrm{f}(1+\mathrm{pg})-\mathrm{rf}-\lambda \mathrm{pt}](\mathrm{A}-\hat{\mathrm{A}})$. 
With (I), the joined profits are decreasing in $\hat{A}$ and so will be maximized for $\hat{A}=0$ (II).

The main reason is that the gain in bribery on both sides increases faster with the degree of under-valuation than the expected costs in terms of additional penalties.

Therefore, each time the controller highlights degradation, A, and rejects the bribe, he reports the true level of degradation. To make it plain, we assume that in this case, the logging company and the controller agree on the bribe that balances their net gains, that is to say:

Taking into account II, this implies that:

$$
\left[1-\lambda\left(1+p_{g}\right)\right] f(A-\hat{A})-b=b-\left(r f+\lambda p_{t}\right)(A-\hat{A}) \text {. }
$$

$$
\mathrm{b}=1 / 2\left\{\left[1-\lambda\left(1+\mathrm{p}_{\mathrm{g}}\right\}+\mathrm{r}\right] \mathrm{f}+\lambda \mathrm{p}_{\mathrm{t}}\right\} \mathrm{A}
$$

What is the effect of this compensation measure as compared to the primary objective of the regulation of forest degradation? Condition (III) shows that if the practice of bribe-giving continues, a slight increase in the reward of the controller, or a penalty for taking the bribe, $\mathrm{p}_{\mathrm{t}}$, will simply increase the level of bribe, so the controller will ask for and receive a larger bribe. In such circumstances, bribery increases.

But if the reward or penalty is sufficiently increased to reverse the relationship (I), bribery could collapse. Thus, the demand of the controller increases beyond the good will of the logging company to pay the bribe and bribery disappears. If the company does not want to go so far, one way to reduce the bribe is to raise the penalty, $\mathrm{p}_{\mathrm{g}}$, on the bribe-giver (the logging company), reducing the penalty, $\mathrm{p}_{\mathrm{t}}$ on the bribe-taker (the controller). This contrasts with the usual practice of punishing the bribe-giver less severely than the bribe-taker.

Analyzing the Mookherjee and P'ng model, Bardhan P. (1997), Mauro, Paolo (1995) states that a higher reward will encourage the controller to be more vigilant and dissuade the logging company from degrading the forest. To him, reducing degradation will discourage the controller from carrying out checks. At equilibrium, the net effect is a reduction of degradation. On the other hand, when the regulator increases the amount of the penalty imposed on the controller, the controller is less likely to do his job well. This reduction in controls can lower the foreseeable penalty for the degrading logging company, which can aggravate degradation. So, although the controller is risk-neutral, the carrot (the reward for mentioning the degradation of the forest in his report) and the stick (the fine for accepting a bribe) may produce opposite effects on the level of degradation. This entire demonstration is not intended to discourage the establishment of an appropriate premium system in the context of bribery, but to highlight the nature of the complexities involved. This analysis also suggests that the reward system should be more oriented towards the impact of the nuisance that the regulator is supposed to fight in priority.

At least two criticisms can be made of the Mookherjee and P'ng model. First, the assumption that the regulator is benevolent seems too simplistic because he can be corrupt and even collude with either the controller or the logging company. Secondly, it can be assumed that the logging company avoids degrading the forest not only to escape the resulting penalty but also to gain a possible reward from the regulator. But beyond these limits, one can wonder if the approach to forest management based on the triplet $\left(\mathrm{r}, \mathrm{p}_{\mathrm{t}}, \mathrm{p}_{\mathrm{g}}\right)$ is applied in Cameroon.

\section{The empirical analysis}

Before presenting the results of the survey, it is necessary to describe the Cameroonian forest management system.

\subsection{The forest management system in Cameroon}

The description of the forest management system will be threefold: the presentation of the forest, the regulatory framework for logging, and the activities of logging companies.

3.1.1. Presentation of the Cameroonian forest

The Cameroonian forest covers an area of 26 million hectares shared out as follows:

- Wet dense forest: $17,500,000$ ha

- Degraded forest: 4,500,000 ha

- Wooded savannah, clear forest gallery: 4000000 ha Total 26,000,000 ha

To these types of forests, we can add other groups of plants such as shrub savannas, tree savannas, mangroves, etc.).

The zoning plan adopted by Cameroon in 1994 on fourteen million hectares located in the southern part of the dense zone provides for the establishment of a permanent forest estate and a non-permanent forest estate. The permanent forest estate ${ }^{1}$ consists of land permanently allocated to the forest and / or wildlife habitat (e.g. national parks and production forests ${ }^{2}$ ). The non-permanent forest estate is forest land that can be used for non-forest uses

\footnotetext{
${ }^{1}$ The forest estate includes state forests and communal forests.

${ }^{2}$ Scope for sustained and sustainable production of lumber or any other forest product; hunting, fishing and gathering rights are regulated.
} 
(e.g. private forests ${ }^{1}$, national forest ${ }^{2}$ and community forests ${ }^{3}$ ). In this set of forest domains, we will focus on trees that are of particular interest at the national and international levels.

a) The trees in Cameroon

Forest inventories carried out by public bodies (formerly CENADEFOR and ONADEF) from 1982 to 1999 on $2 / 3$ of the dense forest area revealed a timber potential of 1.517 billion $\mathrm{m}^{3}$. This volume includes six hundred and nineteen ligneous species. Among these species, three hundred are considered marketable in the form of lumber; the potential for future stems is estimated at 1.494 billion $\mathrm{m}^{3}$. Among the thirteen (13) most abundant species in the zone already inventoried, we can name in order:
1- Fraké
$105800000 \mathrm{~m}^{3}$
2- Ayous
$2500000 \mathrm{~m}^{3}$
3- Tali
$63600000 \mathrm{~m}^{3}$
4- Dabema
5- Sapeli
$29300000 \mathrm{~m}^{3}$
6- Padouk
$29200000 \mathrm{~m}^{3}$
7- Mavingui
$27500000 \mathrm{~m}^{3}$
$16800000 \mathrm{~m}^{3}$
$14700000 \mathrm{~m}^{3}$
9- Bahia
$12200000 \mathrm{~m}^{3}$
10- Ekops
$11600000 \mathrm{~m}^{3}$
11- Niové
$11500000 \mathrm{~m}^{3}$
12- Olong (Bongo)
$11400000 \mathrm{~m}^{3}$
13- Eyong
$11200000 \mathrm{~m}^{3}$
Total

$\overline{437300000 \mathbf{~ m}^{3}}$

The growing potential in current trade is estimated at two hundred and fifty (250) million $\mathrm{m}^{3}$, an average of $42 \mathrm{~m}^{3} /$ ha, including one hundred and ninety-eight (198) million $\mathrm{m}^{3}$ for the thirteen (13) most abundant species. All this suggests that sustained and sustainable forest management can be successfully conducted in this area, with guarantees of supply to local wood processing industries. It is important to ask why the national and international community gives so much value to rainforest trees?

b) Interest in trees

As a rule, it can be argued that forests provide five main types of services: they provide habitat, livelihood and a way of life for forest dwellers, an environment where a wide variety of animal and plant species coexist, the regulation of local and global climatic patterns through evapotranspiration and carbon fixation, soil protection and nutrition and, by extension, good watershed management and prevention of desertification and finally wood for future uses (World Bank, 1992).

Cutting trees may result in the loss of these services depending on the circumstances. If the land is converted to a different use (eg grazing, food crops or urban development), most of the services rendered by the forest are lost. If trees are replanted after felling, or if cutting trees is made highly selective, some or most of the services rendered by the forest may remain, depending on the degree of resistance of each type of forest. Humid or dry tropical forests, like the forests of Cameroon, provide the five services mentioned above (World Bank, 1992). Recent studies, based on remote sensing data and ground surveys, have shown that deforestation, which is currently increasing at 17 to 20 million hectares per year, mainly affects tropical rainforests. Deforestation, which includes the clearing of forests and isolated trees, is explained by the fact that some people find it interesting. Individuals, communities and the companies that are responsible for them vary according to the type of forest. Tree cutting can contribute to short-term economic growth and the fight against poverty. But this is often done to the detriment of other ecological and social objectives, the costs of which are sometimes borne by the country, sometimes by the international community. One can wonder if in the case of Cameroon there is a regulation likely to take these costs into account.

\subsection{The regulatory framework}

Developed in a general context of liberalization and State disengagement in the productive sector, the Law $\mathrm{N}^{\circ}$ 94/01 of 20 January 1994 on the Forest, Wildlife and Fisheries Regime, determines the institutions responsible for forest management in Cameroon on the one hand, and the conditions and procedures for carrying out this activity on the other hand.

In Cameroon, any natural or legal person wishing to exercise a forest activity must first obtain a logging title. With respect to non-profit operations, there is only one type of authorization called "personal cutting authorization",

\footnotetext{
${ }^{1}$ Forests in the national domain are those that do not include yards and agricultural plantations, or secondary woodlots on a farm, or pastoral or agro-forestry developments.

${ }^{2}$ Community forests are those whose resource management is done by village communities.

${ }^{3}$ Community forests are those whose resource management is done by village communities.

${ }^{4}$ CENADEFOR: National Center for Forest Development. ONADEF: National Office of Forest Management.
} 
whereas for the commercial exploitation of timber, there are 3 of them, namely:

- The logging license: It is an authorization to exploit well-defined quantities of forest products in a given zone. These quantities may not exceed $500 \mathrm{~m}^{3}$ of raw wood. Logging licenses for timber are granted after consulting a committee for a maximum of one year non-renewable. These licenses apply only to the nonpermanent forest.

- The sale of firewood: It is an authorization to exploit, for a limited period, a well-stated volume of standing wood in an area not exceeding 2500 ha. Timber sale licenses are granted by MINEF, after consulting a competent commission, for a maximum period of one year non-renewable for state-owned production forests and for a period of three years for the national domain. The sale of firewood applies to both permanent and non-permanent forests.

- The logging agreement: This agreement confers on the beneficiary the right to obtain a given volume of timber from a forest concession to supply its wood processing industry in the long term. The forest concession is the territory on which the logging agreement is exercised. The forest concession is granted after consulting a competent committee. The logging agreement is concluded for a renewable period of 15 years and applies only to permanent forests. It is evaluated every three years. The total area that can be granted to the same forest concessionaire is calculated on the basis of a sustained and sustainable yield and the capacity of the existing processing industries to be put in place. In no case may it exceed 200000 hectares.

To obtain one of these logging authorizations, one must be a physical person residing in Cameroon, a legal entity whose composition of the social capital is known to the administration in charge of the forests and whose headquarters is in Cameroon.

However, the beneficiary of an accreditation may subcontract some of its activities provided he gets the prior agreement of the forest administration. In the context of tree cutting, there are several types of offenses that can be divided into two groups: minor offenses and major offenses. Minors are those that are made because we did not pay the maximum attention to respect the norms of exploitation contained in the specifications (for example nonrespect of the minimal diameter of the tree to be felled). Major offenses include unauthorized logging or beyond the limits granted.

In all cases, the Law 94-01 on the Forest, Wildlife and Fisheries Regime includes offenses with sanctions, some of which are listed below.

Table 1: Examples of fraud and sanctions.

\begin{tabular}{|c|c|}
\hline Some types of fraud & Sanctions \\
\hline $\begin{array}{l}\text { Harvesting in a forest of the national domain for lucrative use, } \\
\text { or beyond the period or quantity granted. } \\
\text { The transfer or hand over of a personal logging permit. }\end{array}$ & $\begin{array}{l}\text { Fine of } 5,000 \text { to } 50,000 \text { XAF }{ }^{1} \text { and } \\
\text { imprisonment of ten (10) days. }\end{array}$ \\
\hline $\begin{array}{l}\text { Exploitation based on a simple permit, unauthorized forest } \\
\text { products, beyond the limits, the allocated volume and / or the } \\
\text { period granted in a forest of the national domain, } \\
\text { Transfer or hand over of a license to another logging company. } \\
\text { The unauthorized felling of protected trees. }\end{array}$ & $\begin{array}{l}\text { Fine of } 50,000 \text { to } 200,000 \text { XAF and } \\
\text { imprisonment for twenty }(20) \text { months. }\end{array}$ \\
\hline $\begin{array}{l}\text { Execution of a management or development inventory that does } \\
\text { not comply with standards set by the forest administration. } \\
\text { Unauthorized logging in a forest of the national domain beyond } \\
\text { the limits and / or the period granted. } \\
\text { The delimitation of logging licenses and actual cutting margins. } \\
\text { Fraudulent use, counterfeiting or destruction of marks, forestry } \\
\text { hammers, posts or poles used by forest administrations. }\end{array}$ & $\begin{array}{l}\text { Fine of } 200,000 \text { to } 1,000,000 \mathrm{XAF} \text { and } \\
\text { imprisonment from one month to six months } \\
\text { or one of two penalties. }\end{array}$ \\
\hline $\begin{array}{l}\text { Logging firewood in a state forest, beyond the limits of cutting } \\
\text { quotas and / or the period granted. } \\
\text { Fraudulent exploitation by a subcontractor as part of a } \\
\text { subcontracting agreement in a state forest. }\end{array}$ & $\begin{array}{l}\text { Fine of } 1,000,000 \text { to } 3,000,000 X A F \text { and } \\
\text { imprisonment of six }(06) \text { months to one }(01) \\
\text { year or one of two penalties. }\end{array}$ \\
\hline $\begin{array}{l}\text { Unauthorized logging in a state or communal forest. } \\
\text { Exploitation beyond the limits of the forest concession and/or } \\
\text { volume and period granted. Transfer of a cut sale or concession } \\
\text { without authorization. } \\
\text { Falsification or fraud from any document issued by the forest } \\
\text { administrations. }\end{array}$ & $\begin{array}{l}\text { Fine of } 3,000,000 \text { to } 10,000,000 \mathrm{XAF} \text { and } \\
\text { imprisonment of one }(01) \text { to three }(03) \text { years or } \\
\text { one of the penalties. }\end{array}$ \\
\hline
\end{tabular}

Source: MINEF.

${ }^{1} 1 \mathrm{EUR}=655.957 \mathrm{XAF}$. 


\subsubsection{Logging companies and their activities}

The activities of the wood industry are diverse. They include cutting wood, sawing, slicing, carpentry, cabinet making, poles, carbonization, etc.

To date, logging is carried out on about 9 million hectares of productive rain forest. The register of economic operators in the forest sector has more than 400 approved operators.

Among the licensed but inactive operators, there are many national sole proprietorships.

Out of the 400 companies registered in the Forest Directorate, only 78 are active. There are usually two types of forest companies:

- Unprotected loggers who exploit timber under permits granted to them and sell the raw timber in or out of Cameroon.

- Logging companies with primary processing unit. These are the operators who buy their logs either through their own exploitation titles or from other operators. The logs thus obtained are made of veneer and sawn timber.

\section{2- The results of the investigation}

Before presenting the results themselves, it is important to recall the methodological approach that we adopted.

\subsubsection{The methodology}

This methodology consists in limiting the population to study and making a questionnaire tailor-made for the individuals who will be questioned. The main population consists of all participants in the forest management process. There are seven types of agents: MINEF controllers, logging companies, territorial and judicial officials, law enforcement agencies, non-governmental organizations and finally, the populations benefiting from user rights. Indeed, MINEF is the regulator of the forest system in Cameroon. As such, we assume that the wish of MINEF is for trees to be exploited according to the rules in force. To achieve this objective, MINEF mandates the controllers who supervise the activities of loggers. Both controllers and operators are the main participants in tree management. All other participants have a secondary function of support and assistance to the forest administration. In this sense the police secure the controllers in their control activities, while the judicial authority ensures the application of the cases of repression of some offenses when, for example an operator does not observe the sanctions prescribed by the Minister of Environment and Forests. In the end, the population actually surveyed is reduced to forest operators and controllers. The activities carried out by the controllers are credited thanks to the observation of the Non-Governmental Organizations and in particular Global Witness who participates as a witness in almost all the control actions carried out by the central control unit of MINEF.

The fact that bribery has been one of the most criticized scourges in Cameroonian media in recent days made the investigation difficult. This difficulty is due to the fact that respondents did not want to question their morality. Also, we avoided asking them if they were themselves bribe-takers or bribe-givers, for fear of increasing the risk of no or false answers as most of them did not want to reveal their real identity. We thought fit to get them to give their opinion on the corrupt behavior of the other actors of the logging activity which they are supposed to know well. To help respondents express their opinions, we provided them with a LIKERT-type scale. It is a scale of measurement of the attitudes where the interviewee is asked to place himself on a continuum about a series of statements relating in principle to the same subject, and for which he must express his degree of agreement or disagreement by choosing between five categories of responses: strongly agree (1 '), somewhat agree (2'), do not agree (3 '), disagree (4'), strongly disagree (5'). At first 78 operators and 110 forest controllers were interviewed. In most cases the investigators met with people to interview in their office. The questionnaire was often filled in on the spot. At times, the investigator was obliged to come back and collect questionnaires already answered. During the counting operation, 62 questionnaires correctly filled in by the operators were validated. As concerns controllers 70 questionnaires were validated. We used the SPSS software for data processing. The objective of the questionnaires was to find out whether the instrument triplet $\left(\mathrm{r}, \mathrm{p}_{\mathrm{t}}, \mathrm{p}_{\mathrm{g}}\right.$ ) proposed by Mookherjee and P'ng is used by the Ministry of Environment and Forests for a better management of trees in Cameroon. Therefore, it was question to ensure the existence of this triplet in Cameroon and possibly measure the existing correlations between the various instruments that constitute this triplet. In general, these results can be presented according to whether they are from forest controllers or logging companies. We will designate the forest operator, forest controller by $(\mathbf{e}, \mathbf{c}) ; \mathbf{A}^{\prime}$ is the absolute frequency of the respondents, $\mathbf{R}$ is the valid percentage of these respondents.

\subsubsection{The controllers}

The investigation revealed at the level of controllers, the existence of a bribery game (Table 2), the absence of a reward depending on the degradation of forests and bribery on the one hand (Table 3), and a penalty for underestimating the degradation ratio on the other hand (Table 4). 
Table 2: Different levels of bribery according to forest controllers.

\begin{tabular}{|l|c|c|c|c|c|c|c|c|c|c|c|c|}
\hline \multirow{2}{*}{$(\mathbf{e}, \mathbf{c})$} & \multicolumn{2}{|c|}{$\mathbf{1}$} & \multicolumn{2}{|c|}{$\mathbf{2}^{\prime}$} & \multicolumn{2}{|c|}{$\mathbf{3}^{\prime}$} & \multicolumn{2}{c|}{$\mathbf{4}^{\prime}$} & \multicolumn{3}{|c|}{$\mathbf{5}^{\prime}$} & \multicolumn{2}{|c|}{ Total } \\
\cline { 2 - 22 } & $\mathbf{A}^{\prime}$ & $\mathbf{R}$ & $\mathbf{A}^{\prime}$ & $\mathbf{R}$ & $\mathbf{A}^{\prime}$ & $\mathbf{R}$ & $\mathbf{A}^{\prime}$ & $\mathbf{R}$ & $\mathbf{A}^{\prime}$ & $\mathbf{R}$ & $\mathbf{A}^{\prime}$ & $\mathbf{R}$ \\
\hline Bribery by gifts & 10 & 14.5 & 5 & 7.2 & 44 & 63.8 & 6 & 8.7 & 4 & 5.8 & $\mathbf{6 9}$ & \\
\hline Bribery by money & 10 & 14.7 & 36 & 52.9 & 10 & 14.7 & 9 & 13.2 & 3 & 4.4 & & $\mathbf{1 0 0}$ \\
\hline
\end{tabular}

Source: Our surveys.

The answers to the question about whether bribery exists in the labor relationships between logging companies and controllers show a general tendency to corrupt practices here and there. Overall, $67.6 \%(14.7 \%+$ $52.9 \%$ ) of the controllers surveyed believe that logging companies offer bribes to some of their colleagues while only $17.6 \%(13.2 \%+4 \%)$ of controllers have a different opinion. For example, through bribery, logging companies can cause controllers to underestimate reports on forest degradation.

Table 3: The different levels of reward of controllers depending on the fines imposed on logging companies.

\begin{tabular}{|l|c|c|c|c|c|c|c|c|c|c|c|c|}
\hline \multirow{2}{*}{$(\mathrm{e}, \mathrm{c})$} & \multicolumn{2}{|c|}{$\mathbf{1}^{\prime}$} & \multicolumn{2}{|c|}{$\mathbf{2}^{\prime}$} & \multicolumn{2}{c|}{$\mathbf{3}^{\prime}$} & \multicolumn{2}{|c|}{$\mathbf{4}^{\prime}$} & \multicolumn{3}{|c|}{$\mathbf{5}^{\prime}$} & \multicolumn{3}{c|}{ Total } \\
\cline { 2 - 15 } & $\mathbf{A}^{\prime}$ & $\mathbf{R}$ & $\mathbf{A}^{\prime}$ & $\mathbf{R}$ & $\mathbf{A}^{\prime}$ & $\mathbf{R}$ & $\mathbf{A}^{\prime}$ & $\mathbf{R}$ & $\mathbf{A}^{\prime}$ & $\mathbf{R}$ & $\mathbf{A}^{\prime}$ & $\mathbf{R}$ \\
\hline Bribery by gifts & 4 & 5.8 & 2 & 2.9 & 1 & 1.4 & 18 & 26.1 & 44 & 63.8 & $\mathbf{6 8}$ & $\mathbf{1 0 0}$ \\
\hline
\end{tabular}

Source: Our surveys.

Table 3 shows us that $89.9 \%$ of controllers surveyed say they do not benefit from a reward depending on the fines that accomplices pay for having degraded the forest, while $8.7 \%$ admit to benefit.

Table 4: The different levels of penalties imposed on the controller who is corrupted by a logging company.

\begin{tabular}{|c|c|c|c|c|c|c|c|c|c|c|c|c|}
\hline \multirow{2}{*}{$(e, c)$} & \multicolumn{2}{|c|}{ 1' } & \multicolumn{2}{|c|}{ 2' } & \multicolumn{2}{|c|}{3,} & \multicolumn{2}{|c|}{4 ' } & \multicolumn{2}{|c|}{5} & \multicolumn{2}{|c|}{ Total } \\
\hline & $\mathbf{A}^{\prime}$ & $\mathbf{R}$ & $\mathbf{A}^{\prime}$ & $\mathbf{R}$ & $\mathbf{A}^{\prime}$ & $\mathbf{R}$ & $\mathbf{A}^{\prime}$ & $\mathbf{R}$ & $\mathbf{A}^{\prime}$ & $\mathbf{R}$ & $\mathbf{A}^{\prime}$ & $\mathbf{R}$ \\
\hline Controllers interviewed & 4 & 5.8 & 2 & 2.9 & 1 & 1.4 & 15 & 21.7 & 46 & 66.7 & 66 & 100 \\
\hline
\end{tabular}

Source: Our surveys.

The surveys also examined whether the Department often imposes penalties on controllers who, in collusion with the logging company, underestimate the level of forest degradation. Table $\mathrm{n}^{\circ} 3$ above indicates that for $88.4 \%$ of the controllers interviewed, there are no penalties against some of their colleagues who are corrupt and underestimate, bias or falsify reports on forest degradation. On the other hand, there are administrative sanctions against unscrupulous controllers. These are usually disciplinary transfers to remote localities, blames and warnings. It may happen on rare occasions that the civil servant loses his position as controller. The Law No. 94-01 of 20 January 1994 on forestry, wildlife and fisheries provides in Article 150 that accomplices, or all those who have participated in one way or another in offense are punishable by the same penalties as the author of the offense. The consequence is that the corrupt controller should for example pay the same fine as the offending operator. Investigations show that this law is not applied, at least on the side of controllers. But if it were applied, could civil servants pay fines as high as those paid by logging companies? For example: the perpetrator of any of the following infringements is punished with a fine of three to ten million XAF and an imprisonment term of one to three years, or one of the two penalties only:

- Unauthorized logging in a public or communal forest;

- Logging beyond the limits of the forest concession and / or the volume and the period granted. Table 5: The reward received by a controller based on the auction sale of confiscated logs.

\begin{tabular}{|c|c|c|c|c|c|c|c|c|c|c|c|c|}
\hline \multirow{2}{*}{$(e, c)$} & \multicolumn{2}{|c|}{ 1' } & \multicolumn{2}{|c|}{2} & \multicolumn{2}{|c|}{ 3' } & \multicolumn{2}{|c|}{4 ' } & \multicolumn{2}{|c|}{5} & \multicolumn{2}{|c|}{ Total } \\
\hline & $\mathbf{A}^{\prime}$ & $\mathbf{R}$ & $\mathbf{A}^{\prime}$ & $\mathbf{R}$ & $A^{\prime}$ & $\mathbf{R}$ & $\mathbf{A}^{\prime}$ & $\mathbf{R}$ & $\mathbf{A}^{\prime}$ & $\mathbf{R}$ & $\mathbf{A}^{\prime}$ & $\mathbf{R}$ \\
\hline Controllers interviewed & 14 & 20 & 33 & 47.1 & 1 & 1.4 & 13 & 18.9 & 9 & 12.9 & 70 & 100 \\
\hline
\end{tabular}

Source: Our surveys.

The table above shows that controllers $(20 \%+47,1 \%=67.1 \%)$ receive bonuses resulting from the auctioning of timber logs owned by logging companies that have committed an infringement. However, interviews with noncontrollers of MINEF staff revealed that all of them benefited from these bonuses. The bonuses cannot therefore be a particular incentive for controllers who make objective and reliable reports on forest degradation by logging companies. In fact, these controllers believe that they should be the ultimate beneficiaries; extending the sharing of bonuses to staff members who are not controllers (or even to unscrupulous controllers) has the effect of reducing the share received by each of them.

In the light of all this information, it can be said that the forest management system regulator in Cameroon (MINEF) has neither a reward rate $(r)$ nor a penalty rate $\left(\mathrm{p}_{\mathrm{t}}\right)$ in the sense of Mookherjee and $\mathrm{P}$ 'ng. The fact that this regulator does not have these instruments can appear as one of the essential causes of the anarchic exploitation of forests and thus of their sustainable management crisis. What about logging companies?

3.2.3. Forestry operators

The survey revealed at the level of logging companies, the existence of a bribe game (Table 6) and the absence of penalties relating to this game (Table 7). 


\begin{tabular}{|l|c|c|c|c|c|c|c|c|c|c|c|c|}
\hline \multirow{2}{*}{$(\mathbf{e}, \mathbf{c})$} & \multicolumn{2}{|c|}{$\mathbf{1}^{\prime}$} & \multicolumn{2}{|c|}{$\mathbf{2}^{\prime}$} & \multicolumn{2}{|c|}{$\mathbf{3}^{\prime}$} & \multicolumn{2}{|c|}{$\mathbf{4}^{\prime}$} & \multicolumn{2}{|c|}{$\mathbf{5}^{\prime}$} & \multicolumn{2}{c|}{ Total } \\
\cline { 2 - 14 } & $\mathbf{A}^{\prime}$ & $\mathbf{R}$ & $\mathbf{A}^{\prime}$ & $\mathbf{R}$ & $\mathbf{A}^{\prime}$ & $\mathbf{R}$ & $\mathbf{A}^{\prime}$ & $\mathbf{R}$ & $\mathbf{A}^{\prime}$ & $\mathbf{R}$ & $\mathbf{A}^{\prime}$ & $\mathbf{R}$ \\
\hline Usual bribe & 16 & 27.1 & 41 & 69.1 & 1 & 1.7 & 1 & 1.7 & & & $\mathbf{5 9}$ & $\mathbf{1 0 0}$ \\
\hline Bribe known in advance & 37 & 60.7 & 19 & 31.7 & 1 & 1.6 & 4 & 6.6 & & & $\mathbf{6 1}$ & $\mathbf{1 0 0}$ \\
\hline Effective bribe & 26 & 45.6 & 30 & 52.6 & 1 & 1.8 & & & & & $\mathbf{5 7}$ & $\mathbf{1 0 0}$ \\
\hline Bribe in fear of paying more & 23 & 39 & 24 & 40.7 & 6 & 10.2 & 6 & 10.2 & & & $\mathbf{5 9}$ & $\mathbf{1 0 0}$ \\
\hline Bribe paid in several stages & 23 & 39.7 & 32 & 55.2 & 3 & 5.2 & & & & & $\mathbf{5 8}$ & $\mathbf{1 0 0}$ \\
\hline Bribe canceling the offense & 27 & 45 & 25 & 41.7 & 4 & 6.7 & 4 & 6.7 & & & $\mathbf{6 0}$ & $\mathbf{1 0 0}$ \\
\hline Bribe as the logger's pass & 47 & 77 & 14 & 23 & & & & & & & $\mathbf{6 1}$ & $\mathbf{1 0 0}$ \\
\hline
\end{tabular}

Source: Our surveys.

Reading Table 6 essentially shows that the overwhelming majority admit the existence of a bribe game in their sector of activity. Indeed, $96.6 \%$ of logging companies believe that their counterparts usually bribe controllers whether their logging activities are legal or illegal. $92.2 \%$ of them believe that their colleagues know in advance the amount to be paid to bribe forest administrations. $98.2 \%$ of logging companies say that once the bribes are paid to forestry administrators, their counterparts receive the services they expected, especially in the administrative procedures for licensing or cancelling the offenses committed. The survey also reveals that $79.7 \%$ express the fear of logging companies bribing administrators in addition to what is known as normal bribes. $94.9 \%$ say that other operators must pay bribes in several stages leading to the completion of an administrative file. $86.7 \%$ believe that offending operators negotiate bribes with forest controllers in order to reduce or cancel the fine for this offense. Finally, all of them state that companies give bribes at police checkpoints to facilitate the transportation of their logs from the forests to processing plants, lumber yards or ports of shipment.

Table 7: The penalty suffered by logging companies for bribery.

\begin{tabular}{|l|c|c|c|c|c|c|c|c|c|c|c|c|}
\hline \multirow{2}{*}{$(\mathbf{e}, \mathbf{c})$} & \multicolumn{2}{|c|}{$\mathbf{1}^{\prime}$} & \multicolumn{2}{|c|}{$\mathbf{2}^{\prime}$} & \multicolumn{2}{|c|}{$\mathbf{3}^{\prime}$} & \multicolumn{2}{|c|}{$\mathbf{4}^{\prime}$} & \multicolumn{3}{|c|}{$\mathbf{5}^{\prime}$} & \multicolumn{2}{c|}{ Total } \\
\cline { 2 - 25 } & $\mathbf{A}^{\prime}$ & $\mathbf{R}$ & $\mathbf{A}^{\prime}$ & $\mathbf{R}$ & $\mathbf{A}^{\prime}$ & $\mathbf{R}$ & $\mathbf{A}^{\prime}$ & $\mathbf{R}$ & $\mathbf{A}^{\prime}$ & $\mathbf{R}$ & $\mathbf{A}^{\prime}$ & $\mathbf{R}$ \\
\hline Penalty for operator bribery & 0 & 0 & 2 & 3.3 & 23 & 39 & 29 & 49.2 & 5 & 8.5 & $\mathbf{5 9}$ & $\mathbf{1 0 0}$ \\
\hline
\end{tabular}

Source: Our surveys.

Table 7 shows that only $3.3 \%$ of logging companies believe that a logger can pay a penalty for bribing to a forest administrator. On the other hand, $57.7 \%$ deny the existence of such a penalty. Field data suggests that the forest management system regulator in Cameroon does not have the penalty $\left(\mathrm{p}_{\mathrm{g}}\right)$. The absence of such a penalty may appear as a significant explanatory factor for the wild exploitation of forests in this country, thus compromising the intergenerational balance in the management of forestry.

\section{Conclusion}

The purpose of this paper was to provide, in the light of the Mookherjee and P'ng model, an alternative explanation to the crisis of sustainable forest management in Cameroon. Field data shows that bribery has profoundly affected the sustainable management of forestry. This phenomenon is highlighted in the bribery game between logging stakeholders, especially the couple $(\mathrm{e}, \mathrm{c})$. In its attempt to rationalize logging and thus preserve the intergenerational balance, MINEF does not have the management and control instruments proposed by the model: a reward rate $(\mathrm{r})$ and a penalty rate $\left(\mathrm{p}_{\mathrm{t}}\right)$ aimed at getting public forest controllers to draw up objective and reliable forest degradation reports, a penalty rate $\left(\mathrm{p}_{\mathrm{g}}\right)$ aimed at dissuading logging companies from corrupting controllers. The absence of these instruments appears to be one of the fundamental causes of the crisis of sustainable forest management and its aggravation in the country. In terms of recommendation, it is advisable for MINEF to adopt and ensure the application of $r, p_{t}$, and $p_{g}$. However, the adoption and application of these instruments may not be enough to guarantee the end of this crisis as the financial greed of both logging companies and controllers can oppose to the clean-up of the forestry sector. The recommendation can go beyond the only instruments proposed by the model, by introducing a reward rate ( $\mathrm{r}$ ') that would benefit the logging company that best respects the regulation about cutting trees.

\section{References}

Aidt, Toke S. (2003), "Economic Analysis of Corruption: A Survey". Economic Journal 113: F632-652.

Aidt, Toke S. (2009), "Corruption, Institutions and Economic Development", Oxford Review of Economic Policy 25:271-291.

Aidt, Toke S. (2012), Corruption and Sustainable Development, CWPE, 1061, 52 pages.

Banque Mondiale (1992), « Le secteur forestier », Document de politique générale Washington, D.C.

Bardhan, Pranad (1997), "Corruption and Development: A Review of Issues", Journal of Economic Literature XXXV: 1320-1346.

Brundland G.H. (1998), Notre avenir à tous, Editions du fleuve, Publications du Québec, Montréal. Capul J.Y., Garnier O. (2005), Dictionnaire d'Economie et Sciences Sociales, Hatier, Paris. 
Lauriol J. (2004), Développement durable et corps de doctrine, Revue. Française de Gestion Vol XXX (152), p.137-150.

Leite C., Weidmann J. (1999), Does mother nature corrupt? natural resource, corruption and economic growth, IMF Working Paper, WP /99/85, p. 1-34.

Lettre Verte (2001), Afrique Centrale: Vers une harmonisation des politiques forestières, $n^{\circ} 001$, MINEF.

Mauro, Paolo (1995), "Corruption and Growth", Quarterly Journal of Economics 110: 681-712.

MINEF (1994), Recueil des textes officiels relatifs à la gestion des forêts et de la faune au Cameroun.

MINEF (1999), Séminaire national sur le contrôle des activités forestières, Document de stratégie, Novembre, Yaoundé.

Mookherjee, D., P' NG I.P.L. (1995), “Corruptible law enforcers: How should they be compensated?', Eco. Jour. Vol CV (428).p.145-159. 